\title{
Territorial Delegates and Party Balance: House Committee Membership after 1970
}

\author{
Cameron DeHart*
}

April 1, 2020

\begin{abstract}
Non-voting delegates have represented territories in Congress since 1797, but have only been able to vote in committees in the last half century. The 1970s reforms to expand delegates' rights and create new seats coincided with other party-driven changes to the committee system, and little is known about the impact delegates had on party ratios in committees. In this paper, I present evidence that the addition of delegates to standing committees in the 1970s, as well as the Committee of the Whole in the 1990s, increased Democrats' seat share relative to the margin on the floor. In light of this evidence, the disagreements about the scope of delegates' participation in the House are best understood in the context of increasing polarization and partisanship that increased the stakes of packing committees on the margin.
\end{abstract}

Keywords: Congress, House of Representatives, Deck Stacking, Committee packing, Committee of the Whole, Nonvoting delegates, Territorial delegates

*Stanford University, Department of Political Science 
"[House Democrats] are again using the Constitution as a political Handiwipe and extending full voting rights to favored rotten boroughs...Democrats once stood for one man, one vote. Today on the floor of the House, they stand for one Samoan, 10 votes. Vote this down."

Rep. Phil English (R-PA) in 2007 debate over delegate voting in Committee of the Whole

When Democrats took control of the House of Representatives in 2019, their first rule change extended privileges to the six nonvoting delegates that represent D.C. and the U.S. territories. ${ }^{1}$ House Democrats were restoring partial voting privileges that the GOP had rescinded in 2011. In fact, the 2019 rule was the fifth change to the scope of delegates' participation since 1993, when the Democratic majority first allowed delegates to vote on amendments in Committee of the Whole. As the procedural back-and-forth suggests, and the above quote from Representative English articulates, delegate participation in Congress has been fiercely contested and split along party lines.

Territorial delegates have served in the House since the 18th century, but rules changes in the last 50 years have given these members new significance. The debate over delegate voting in Committee of the Whole was preceded by reforms in the 1970s that created new delegate seats and permitted delegates to vote in standing committees. It is unclear, however, what effect these reforms had on party balance in the committee system, and to what extent parties behaved strategically in enhancing or restricting the delegates' participation.

In this paper, I provide the first empirical analysis of the impact that territorial delegates had on committee sizes and party balance after 1970. Motivated by the literature on committee packing in Congress, I evaluate the extent to which Democratic majorities have used territorial delegates to gain a numerical advantage in the committee system. Second, I explore the ways in which Republicans in the House minority opposed delegate participation, including the party's systematic opposition to delegate voting in Committee of the Whole. The paper focuses on the two historical periods that coincide with the two major delegate voting reforms: the 1970s and the early 1990s.

\footnotetext{
${ }^{1}$ The current delegates represent D.C., Guam, U.S. Virgin Islands, American Samoa, the Northern Mariana Islands, and Puerto Rico, where the office is called "resident commissioner".
} 
The paper proceeds as follows. First, I present background information on the office of nonvoting delegate and theories of committee packing. Next, I examine the factors that led to the House changing delegates' privileges in standing committees and Committee of the Whole. The majority's cartel-like control over the House's procedural rules grants party leadership discretion over how delegates participate, and I argue there is a partisan basis to the expansion, and restriction, of the delegates' parliamentary rights. In the empirical section, I analyze committee membership data from 1970 to 1994 and find that, on average, the delegates increased Democratic representation on standing committees and Committee of the Whole (hereafter "CotW") relative to the party's share of seats on the floor. When delegates were added to standing committees, the majority party became more over-represented in $60 \%$ of cases. Drawing on newly-collected CotW votes, I estimate the delegates' ideal points and show that delegate voting moved the CotW median $2 \%$ closer to the majority party median in the 103rd Congress.

Although this paper focuses on party behavior in Congress, my study also contributes to our understanding of the territorial delegates and their place in the American politics. Among other things, the delegates provide an opportunity to evaluate partisan theories of organization in a different context (Lewallen 2017). ${ }^{2}$ This research also draws on and expands the literature of non-voting members in other legislatures, including Maine's tribal representatives, and designated parliamentary seats for colonial residents (e.g. Overseas Territories in France) and political minorities (e.g. the Maori in New Zealand).

${ }^{2}$ A recent issue of PS: Political Science \& Politics featured a Symposium on teaching the U.S. territories (Vol.50, Issue 2-April 2017). The Symposium joins just four other articles that address non-voting delegates in American politics: Lewallen \& Sparrow (2018), Holtzman (1987), Stewart \& Weingast (1992), and McCarty, Poole, and Rosenthal (2000). 


\section{Background}

\section{Territorial delegates in the House}

The Constitution gives Congress the authority to "dispose of and make all needful rules and regulations respecting the territory or other property belonging to the United States" (Article IV, Section 3). To that end, the House of Representatives permits residents living in the territories to elect a delegate to serve on their behalf. Non-voting delegates have served in every session since 1793, with the exception of the 5th Congress, but the non-voting delegates represented territories that were destined for statehood. The addition of Puerto Rico and the Philippines in the late 19th century marked a departure from that tradition - in the nation's history, 27 territories sent delegates to the House before reaching statehood, and 7 territories elected delegates without a path to statehood. ${ }^{3}$

The function of the territorial delegates prior to the 20th century was to advise members of Congress on local affairs and relevant legislation, and to help build legislative and political talent within the territory before statehood (Holtzman 1986). Historical delegates were active participants in standing, special, and conference committees in various periods before the $1970 \mathrm{~s},{ }^{4}$ and several delegates went on to represent their states as representatives and senators, as governors, and, once, as President of the United States. ${ }^{5}$

Today, the territorial delegates approximate the House members in the privileges, rights, and powers they can exercise in office. ${ }^{6}$ Since the delegates are not constitutional members of Congress, they can neither cast votes on the floor nor file discharge petitions. Delegates also may not preside

\footnotetext{
${ }^{3}$ The District of Columbia previously sent a delegate from 1871 to 1874 .

${ }^{4}$ Delegates could serve on, but not vote in, standing committees from 1871 to 1970 . Rules changes in the 1870s-80s designated the territorial delegates as additional members on the Committee on the Territories, the Committee for the District of Columbia, and others, but they were denied seniority rights (Palmer 2006). The Legislative Reorganization Act of 1946 once again restricted the delegates' rights in committees. Delegates were limited to serving as non-voting additional members on just three committees: Agriculture, Armed Services, and Public Lands (later called Interior and Insular Affairs).

${ }^{5}$ William Henry Harrison, ninth President of the United States, served as the Northwest Territory delegate (1799-1800).

${ }^{6}$ House Rule III, Clause 3 stipulates the delegates' rights and privileges.
} 
over the floor, vote for the House speaker, or sign another member's discharge petition. By virtue of lacking a floor vote, the delegates and their constituents are shut out from important legislative action such as filing motions to reconsider, voting on Constitutional amendments, declaring war, breaking ties in the Electoral College, and resolving disputes over the president's fitness to govern under the 25th amendment. Delegates today serve as their territories' sole federal representatives, and they lack "ready-made allies" from the same constituency with whom they can share labor and advance legislation (Holtzman 1986).

The origin of the modern non-voting delegates is found in the package of reforms passed by Congress in the early 1970s. Liberal members in the majority party, as well as junior representatives in both parties, supported a series of rules changes that dramatically altered how the committee system worked (Binder 1996, Schickler and Rich 1997). During the debate over the Legislative Reorganization Act of 1970, Puerto Rico's resident commissioner Jorge Cordova introduced an amendment to allow territorial delegates to serve on any standing committee. Previously, Cordova was limited to serving as an "additional members" on three committees and could not accrue seniority. He argued that the loss of three guaranteed non-voting committee seats was justified by the opportunity to be appointed, vote, and accrue seniority in the delegates' preferred committee(s). ${ }^{7}$

The House passed the Cordova amendment by voice vote, and re-affirmed the rules changes in 1971 and 1973 to extend the same committee rights, powers, and privileges to the D.C., Guam, and U.S. Virgin Islands delegates. ${ }^{8}$ These rules changes opened the door for the majority party to use the territorial delegates strategically: there was no functional difference between House members and delegates on committees. Cordova hinted at the implications in 1970, and acknowledged his colleague's concerns about the impact of delegate voting on congressional politics. "[T]here is undoubtedly a specter haunting the minds of many in this Chamber as you consider my amendment:

\footnotetext{
${ }^{7}$ Congressional Record, vol. 116 (09-15-1970), pp. 31848-31852

${ }^{8}$ The House elected Puerto Rico's resident commissioner to the Interior and Insular Affairs committee, and the D.C. delegate was given a designated seat on the D.C. committee. Two years later, the Guam and U.S. Virgin Islands delegates joined the Interior committee, the resident commissioner was elected to Education and Labor, and the D.C. delegate joined Banking and Currency (Holtzman 1986).
} 
the specter of other possible Delegates. It haunts those who favor the granting of representation to other communities...lest the broadening of the privileges of the Resident Commissioner may render more difficult their efforts to obtain representation for these other communities. And it probably haunts those who hesitate to grant representation to one or more of these communities."9

\section{The partisan basis of delegates' parliamentary rights}

It is within the powers of the majority party to change the rules governing delegate participation, and it is plausible that both parties manipulate these rules according to their perceptions of how delegate voting will impact their ability to control outcomes. Looking forward from 1970, majority leadership knew it could call on Cordova and future delegates to pad the party's share of seats on standing committees if the new delegates were co-partisans. On the face of it, how plausible is the idea that territorial delegates could benefit Democrats in the House? In fact, the vast majority of non-voting delegates since 1970 have caucused with the Democratic Party. Table 1 presents the party composition of the delegate seats over that time period, measured by the number of House sessions each territory was represented by a member from either party.

Since 1970, the territories and D.C. have been represented by Democrats for at least $80 \%$ of House sessions. Although the trend favors Democrats, Republicans are not precluded from holding delegate seats. On the one hand, District of Columbia and the Northern Mariana Islands have never been represented by Republicans in the House. American Samoa and Guam, on the other hand, have been represented by Republicans in two and four House sessions, respectively. Republicans have also competed for seats in Guam and the Northern Mariana Islands, and as of 2020, they hold the seats in American Samoa and Puerto Rico.

Given the trend toward Democrats holding delegate seats, to what extent is there a partisan basis for extending delegates' rights in the House? Based on the literature on the partisan basis of parliamentary rights (Binder 1996), I consider the following hypothesis:

H1: When the partisan makeup of the delegates favors the majority party, the majority will

\footnotetext{
${ }^{9}$ Congressional Record, vol. 116 (09-15-1970), pp. 31848-31852
} 
Table 1: Party Composition of Territorial Delegates, 1970-2018

\begin{tabular}{|lcccc|}
\hline Territory (1st term) & Perc. Democrats & Democrats & Republicans & Independents \\
\hline Puerto Rico (1901) & $88 \%$ & 21 & 3 & 0 \\
District of Columbia (1971) & $100 \%$ & 24 & 0 & 0 \\
U.S. Virgin Islands (1973) & $91 \%$ & 21 & 1 & 1 \\
Guam (1973) & $83 \%$ & 19 & 4 & 0 \\
American Samoa (1980) $^{\text {Northern Mariana Islands (2008) }}{ }^{1}$ & $89 \%$ & 17 & 2 & 0 \\
\hline
\end{tabular}

${ }^{1}$ Northern Mariana Islands delegate Gregorio K.C. Sablan was elected as an Independent in 2008, 2014, and 2016, but he caucuses with the Democrats. Since autumn 2019, one proposal for a new seat is pending before Congress: a representative for the Cherokee Nation authorized by the Treaty of New Echota (1835).

support proposals to expand delegate rights and the minority party will oppose them.

Table 2 presents a summary of the legislation to extend delegates' parliamentary rights, excluding the proposals to create new seats. The general pattern supports the hypothesis: delegate rights tend to expand under Democrats and not expand under Republicans. Democratic majorities in the 1970s passed legislation written by Democratic members to grant committee rights to new Democratic delegates from D.C., Guam, and the U.S. Virgin Islands. Naturally, these delegates were added to standing committees with the expectation that they would support their party's agenda.

When Republicans gained control of the House in 1995, the new majority allowed the delegates to remain on standing committees, where their minority party status would dull their influence, but prohibited delegates from voting in the Committee of the Whole. Subsequent bills to re-extend CotW voting rights (1998) and grant discharge rights (2004) to delegates died in Republican-led committees. In 1998, the Speaker dismissed a motion by Eleanor Holmes Norton (D-D.C.) to grant the District's delegate a vote in the president's impeachment proceedings. ${ }^{10}$ Delegate voting rights were once again extended when party control of the House changed in 2007, and then reversed again in 2011. Bills to re-extend delegate voting rights in CotW were subsequently blocked in four consecutive GOP-led House sessions (2011 to 2017), before Democrats extended them in 2019 for the third time.

\footnotetext{
${ }^{10}$ Rep. Norton argued D.C. residents were entitled to voting representation in the impeachment process in light of the District's three electoral votes. Interestingly, Norton did not make a similar (public) appeal to Democratic leadership during Donald Trump's impeachment in 2019.
} 
Table 2: Legislation to extend delegates' parliamentary rights, 1970 to 2019

\begin{tabular}{|lcccc|}
\hline Proposed change to delegates' rights & Year & House Majority & Delegates' Party & Outcome \\
\hline Standing committee appointment \& vote & 1970 & $\mathrm{D}$ & 1 D & Passed \\
Reaffirm committee vote for D.C. & 1971 & $\mathrm{D}$ & 2 D & Passed \\
Committee rights to Guam \& USVI & 1973 & $\mathrm{D}$ & 4 D & Passed \\
Committee of the Whole vote & 1993 & $\mathrm{D}$ & 5 D & Passed \\
Committee of the Whole vote $^{1}$ & 1998 & $\mathrm{R}$ & 5 D & Died in Committee \\
Impeachment vote for D.C. delegate & 1998 & $\mathrm{R}$ & 5 D & Rejected by Speaker \\
Discharge rights & 2004 & $\mathrm{R}$ & 4 D, 1 R & Died in Committee \\
Committee of the Whole vote & 2007 & $\mathrm{D}$ & 4 D, 1 R & Passed \\
Committee of the Whole vote $^{2}$ & 2011 & $\mathrm{R}$ & 6 D & Died in Committee \\
Committee of the Whole vote $^{2}$ & 2013 & $\mathrm{R}$ & 6 D & Died in Committee \\
Discharge rights $_{\text {Committee of the Whole vote }}^{2}$ & 2013 & $\mathrm{R}$ & 6 D & Died in Committee \\
Discharge rights & 2015 & $\mathrm{R}$ & 5 D, 1 R & Died in Committee \\
Committee of the Whole vote & 2015 & $\mathrm{R}$ & 5 D, 1 R & Died in Committee \\
Chair of Committee of the Whole & 2017 & $\mathrm{R}$ & 4 D, 2 R & Died in Committee \\
Committee of the Whole vote & 2017 & $\mathrm{R}$ & 4 D, 2 R & Passed \\
\hline
\end{tabular}

${ }^{1}$ The Republican majority revoked CotW voting rights in $1995 .{ }^{2}$ The Republican majority revoked CotW voting rights in 2011.

The sole exception to this trend is illustrative of the rule: in 2017, the Republican majority allowed delegates to serve as the Chair of the Committee of the Whole without voting. Consistent with the hypothesis about the partisan basis for delegates' parliamentary rights, Republicans expanded delegate privileges when the partisan makeup of the delegates was its most favorable in a generation. After the 2016 elections, Republicans increased their share of delegate seats to two and Rep. Amata Radewagen (R-American Samoa) motioned successfully to chair CotW. Crucially, the new rule was not threatening to the party because of the Speaker's role in designating the House's presiding officers: leadership could appoint Radewagen and Puerto Rico's Jenniffer GonzalezColon, the two Republican delegates, to preside Committee of the Whole, while ignoring the four delegates in the minority. 


\section{Delegates on Standing Committees}

\section{Theories of Committee Packing}

Partisan theories of Congress suggest that the majority party tries to design institutions in order to improve its control over legislative outcomes, chiefly through the House rules and the committee system (Cox and McCubbins 1993, 2005). Several scholars have investigated the extent to which the majority party in Congress "packs" committees - giving its members more seats than the party's share of seats in the chamber would warrant. One strand of literature examines the over-representation of the majority party on standing committees (e.g. Rohde 1991, Aldrich and Rohde 2000, Aldrich and Rohde 2001, Sinclair 2006, Jenkins and Monroe 2014), and another investigates packing in conference committees (e.g. Lazarus and Monroe 2007, Vander Wielen and Smith 2011).

The extant literature on committee packing focuses on the majority party's ability to pack standing and conference committees by changing their partisan composition. Regarding standing committees, various scholars point out that the majority party gives itself a higher share of committee seats than its share of seats in the House (Rohde 1991, Jenkins and Monroe 2014, Sinclair 2006, Aldrich and Rohde 2000, Aldrich and Rohde 2001). This is most obvious on the so-called power committees, such as Appropriations and Rules, that have privileged access to the floor. However, it is not limited to those committees. There is evidence that the Speaker of the House appoints loyal members of the majority party to conference committees alongside House members from the bill's jurisdictional committee (Lazarus and Monroe 2007, Vander Wielen and Smith 2011). The consequence of the so-called "Speaker's discretion" to select conference committee members is that the hand-picked majority party members can often secure policy outcomes that are more in line with the majority party's preferences.

Another strand of literature investigates the manipulation of committee size by the majority party to exert control over the policy-making process (Brady and Lee 2016). The most famous example of this expansion strategy was the 1961 Rules Committee, when two Democrats and 
one Republican were added to bypass a bipartisan, conservative coalition that was blocking the majority's agenda with 8-8 votes (Jenkins and Monroe 2014). In the modern Congress, the property rights norm prevents the majority party leadership from removing members from a committee in order to achieve a more desirable ideological composition (Grimmer and Powell 2013). Thus, the majority leaders turn to expanding the number of seats and giving their members a super-proportion of the new seats.

Based on this literature, I consider the following two hypotheses about the impact of adding territorial delegates on committee size and party balance:

H2: When delegates are added to a committee, the majority party will expand the size of the committee rather than replace incumbent members on the committee.

H3: When delegates are added to a committee, the majority party's share of seats on the committee will increase relative to the party's share of seats on the floor.

The logic of packing applies not only to Congressional committees, but to any body of voters such as the Supreme Court (e.g. FDR's 1937 court-packing scheme). ${ }^{11}$ Political parties often register new voters before an election with the hope that adding votes on the margins will push their candidate over 50\%. In each setting, no matter the number of voters, the intention of packing is to achieve a more favorable median voter. In Congress, the House majority uses several tools of procedural control and the minority party responds to those tactics, such that no one form of procedural control is sufficient for majority dominance.

Committee packing is one such tool and, in the context of increasing partisanship, the majority party might have seen the non-voting delegates as a means to increase their procedural control over the House. Given that only five new delegates have been created since 1970, the strategy is clearly not used with much frequency. Despite the obscurity of the institution itself, majority party leaders thought the marginal effect of adding territorial delegates to committees was worthwhile to pursue

\footnotetext{
${ }^{11}$ In expressing his opposition to delegate voting in CoTW in 1993, Rep. Michel invoked Roosevelt's court-packing scheme: "In my mind this House packing scheme is of the same ilk: the use of raw political power which can only be countered by popular outrage. And I believe the American people all across the country are against this grab for more power."
} 
time and time again. And as I discuss later, House Republicans thought delegate voting posed a sufficient threat that they not only opposed Committee of the Whole voting when it was proposed on the floor, but also in federal court and when they regained control of the House in 1995 and 2011.

\section{Alternate theories for delegate voting in 1970s}

Major studies on the extent to which rules changes and parliamentary process in the House benefit majority members do not include the major legislation and rules changes that empowered delegates and created new seats (Cox and McCubbins 1993, 2005; Aldrich and Rohde 2000, Binder 1996, Schickler and Rich 1997). However, there are at least two common explanations for the creation of new delegate seats and expansion of delegate voting.

One account points out that the cause of Guam, U.S. Virgin Islands, and American Samoa were championed by Representative Phil Burton (D-CA), who introduced legislation to create new seats and lobbied fellow Democrats to embrace the delegates as valuable members of the House and the committee system. Burton was reportedly motivated to admit new delegates in order to bypass the chairman of the Interior committee, Wayne Aspinall (D-CO), who allied with Republicans to block liberals' environmental policy priorities. To be sure, the delegates found an ally in Rep. Burton, who helped shepherd their legislation through the committee system, but ultimately the delegates had to rely on the Democratic Party at large to pass laws and secure funding for the territories, given they lack floor votes with which to logroll.

This account is too simplistic, leaving no room for parties or institutions, and reducing historic institutional change to the whims of political entrepreneurs. Given that Democratic leadership and rank-and-file supported Burton's proposals, we're left to wonder if his motivations were distinguishable from the preferences of the median party member. Rep. Burton was undoubtedly an effective policy entrepreneur, but party leaders and other members had their own incentives to support, or challenge, the creation of new delegate seats. At any rate, the Burton account does not disqualify the explanation in which the party sees advantages in creating new delegates once the 
Cordova amendment opens up the possibility for delegate voting in the first place.

The other alternative explanation suggests that social trends, and a leftward shift in Congress, led Democrats and some liberal Republicans to increase their support to the territories. In this story, the impact on party balance in standing committee was incidental. According to this narrative, increasingly liberal Democratic members saw benefits to publicly supporting a range of causes, and by supporting new delegate seats in DC, Guam, U.S. Virgin Islands, and American Samoa, these members could credibly claim that they support self-determination for the people living on the periphery of American empire.

The 1970s saw the rise of identity politics and the elevation of concerns about colonialism, territorial policy, and the treatment of indigenous people and people of color. Social changes, including migration from the territories to the mainland, also loomed large for Democratic members of Congress. Several members expressed their support for the Cordova amendment in light of new Puerto Rican constituents in their district. Rep. Robert McClory (D-IL) spelled out the politics plainly: "In recent conversations with a group of my constituents...I am informed that there are now more than 10,000 local residents who have migrated from their Puerto Rican birthplace. These citizens who are now residents of the 12th Congressional District of Illinois enjoy voting and other rights equal with those of other American citizens...it is my intention to see that those rights are protected and...that the aspirations of these and other Spanish-speaking Americans are fulfilled." 12

The creation of new delegate seats in this decade was, in many ways, a byproduct of growing demands for self-determination in the territories. Nonvoting seats were seen either as a stepping stone to full voting representation, as in D.C., or as a halfway measure to placate more extreme demands for independence, as in Puerto Rico. Rep. Cordova had campaigned for his seat as resident commissioner by calling for further integration of Puerto Rico with mainland politics, and

${ }^{12}$ Congressional Record, vol. 116 (09-15-1970), pp. 31848-31852. Another member, Rep. Edward Patten (D-NJ), remarked, "I would like to be in the parade of the Spanish-speaking people in my community. Sunday night I am going to a banquet, and I would appreciate the House adopting this amendment so I can tell them that I have supported the amendment." 
his amendment was a step in that direction. In the case of the District of Columbia, which had recently gained three electoral votes, liberals in both parties cheered the creation of the delegate seat over the opposition of southern committee chairmen. On the other hand, movements for selfdetermination had been growing in Guam, the US Virgin Islands, and American Samoa since the 1950s, as residents grew increasingly frustrated under the bureaucratic rule of the Defense and Interior departments. Why did Democrats decide to empower and create new delegates in the 1970 s, and not in the 1950 s or 60 s?

Here again the role of parties and party leadership in shaping institutions fades into the background as members are driven by their short-term ideological and electoral concerns. One possibility is that the influx of liberal junior members in the 1970s changed the House's preferences over supporting the territories. But, as the roll call votes in figures 3 and 4 show, however, a good number of liberal members, notably liberal Republicans, voted against creating the D.C., Guam, and U.S. Virgin Islands seats. A more plausible explanation, the one I outline in this paper, is that in a period of increasing partisanship, the Democratic rank-and-file sought a means to shore up their numbers in the low prestige standing committees. It is worthwhile to consider the alternatives.

\section{Packing Committee of the Whole? The fight over amendments}

Previous scholars have not explored the use of non-voting delegates by the majority party to pack the Committee of the Whole, in part, because CotW is operationally different from standing committees. ${ }^{13}$ The CotW's absence from the committee packing literature is not without reason: given that the membership of CotW is the same as the membership of the House, it is unclear that the majority party can pack CotW. On the House floor, the majority cannot unilaterally stack the deck by, for example, replacing deceased or resigned minority members with majority members, nor is the Speaker given the discretion to allow or disallow certain members from participating in floor votes. Furthermore, the majority cannot expand the number of representatives for partisan advan-

\footnotetext{
${ }^{13}$ A notable exception, Espino and Canon (2009), use the re-votes taken in Committee of the Whole during the 103rd Congress to study randomness in voting.
} 
tage on the floor, and the prospects of admitting new states to shift the party balance in Congress are low. ${ }^{14}$ Given these constraints, an otherwise marginal reform, like allowing six delegates to vote on amendments, takes on new strategic potential.

Committee of the Whole is a procedural instrument unique to the lower chamber that allows the House leadership to move through business quickly on the floor. House leadership can move the chamber into CotW in order to pass procedural measures. More importantly, the House can move into CotW to vote on amendments on the floor without returning legislation to the relevant standing committee. The quorum for CotW is just 100 members, rather than the 218 required to consider business on the House floor, allowing leaders to free up their members for other work.

Furthermore, the majority party has the legal authority to amend procedures in Committee of the Whole. CotW is a creation of the House rules and a majority of House members could vote to abolish the body as if it were another standing or conference committee. Since CotW functions more like a committee than like the floor, the majority party is able to pack it using an unusual expansion strategy: at the beginning of the House session, the leadership can amend the rules to grant voting rights in $\mathrm{CotW}$ to the territorial delegates. The majority party cannot run amok in the Committee of the Whole, however, with or without the territorial delegates. The House rules prohibit any action in CotW from altering the proceedings of the House itself, such as changing the order of bills on the House calendar (Beth and Fauntroy 2002). Furthermore, any procedural votes or amendments that pass in CotW can be reviewed and overturned by the House floor.

Rep. Eleanor Holmes Norton (D-D.C.) proposed allowing delegates to vote in CotW in a memorandum at the December 1992 meeting of the House Democratic Caucus, and she rallied liberal members to support it (Broder 1992). To preempt Republican opposition to the rule change, the Democratic majority also amended Rule XXIII to stipulate that the delegates could not be decisive or pivotal in any vote in Committee of the Whole. In the event that the delegates' votes were decisive in the passage or failure of an amendment, the House would reconsider the amendment on the House floor and the delegates would be stripped of their vote. Despite the saving clause, House

\footnotetext{
${ }^{14}$ The membership of the House was fixed at 435 representatives by the 1911 Apportionment Act, and has remained there since 1963 after temporary increases for Hawaii and Alaska.
} 
Republicans proceeded with a lawsuit against the Clerk of the House, suggesting that the minority party thought the addition of delegates to CotW would hurt its ability to impact policy.

If the Democratic House majority supported delegate voting in order to tip the scales in the Committee of the Whole, the strategy was inherently limited. Any 25 members (except delegates themselves) can demand a floor vote for any amendment that passes CotW, whether or not the delegates are pivotal, a strategy that Republicans employed in the 103rd Congress to delay proceedings and strip the delegates of their votes. Although the vast majority of the re-votes did not change the outcome, there is evidence that vote-switching did occur (Espino and Canon 2009). Further limiting their influence as individual members, the delegates could propose amendments, but still lacked discharge rights in CotW. Nevertheless, the extent to which the parties were willing to fight over (and litigate) the delegates' rights suggests that they thought these reforms were meaningful and had the potential to shift policy on the margins.

The question of delegate voting arose before, during the 1970 debate over the Cordova amendment. The debate is illustrative of the Democrats' change of heart on the issue. Skeptics, including floor manager B.F. Sisk, asked whether the amendment allowing delegates to vote in standing committees would also extend, to the delegates, the privileges of voting in Committee of the Whole? Rep. Tom Foley (D-WA) reassured his colleagues that the rule change would only apply to standing committees, and that any proposal to allow delegates to vote in Committee of the Whole, or the floor, would require a constitutional amendment. ${ }^{15}$ Two decades later, as Speaker of the House, Foley would oversee the reforms that allowed delegate voting in CotW. What had changed from 1970 to $1993 ?^{16}$

As I explain in the next sections, the majority party was willing to pursue the strategy to pack CotW in 1993 because there were payoffs for the party and individual members. The two main factors, I argue, were Democrats' concerns about party cohesion on amendment votes, as well as time constraints on the floor.

\footnotetext{
${ }^{15}$ Congressional Record, vol. 116 (09-15-1970), pp. 31848-31852

${ }^{16}$ When asked about his new position on delegate voting, a spokesperson for Speaker Foley said, "He's changed his mind" (Broder 1992).
} 


\section{Defectons on amendment votes}

Throughout the 1980s, the Democrats experienced difficulty maintaining cohesion in CotW to pass parliamentary measures and block amendments (Roberts and Smith 2003). Conservative Democrats were defecting from their party to support Republican-led amendments in Committee of the Whole, on roll calls and voice votes, on items that they might not otherwise support on the floor. Roberts and Smith (2003) present evidence that the parties voted differently in CotW compared to voting on the floor: Republicans voted as a united bloc on both the floor and CotW, but the Democrats experienced lower rates of party cohesion in Committee of the Whole relative to the floor. Amendments in CotW tended to focus on narrow policy issues and Republicans were effective at attracting bipartisan support for ideological and symbolic votes (Roberts 2007), especially after the advent of recorded votes in CotW (Smith 1989).

Given this reality, Democrats sought a way to improve party cohesion in CotW and prevent the minority from passing amendments. Leadership used restrictive rules to block the conservative coalition's amendments (Bach and Smith 1988), but Democrats still suffered defections on those CotW amendment votes that slipped through. By the early 1990s, the majority needed a new strategy to exert control on the margins, where their other procedural tools had failed.

They saw an opportunity in the territorial delegates. If the membership of CotW could be expanded, beyond the membership of the House, it was advantageous for the party leadership to do so. The addition of territorial delegates to CotW gave the majority party some space to protect their moderate members in the face of the Republican amendments.

\section{Time constraints on the floor}

Second, majority parties are concerned about the impact of time constraints on their ability to pass parliamentary business, and these constraints structured the majority's strategies for achieving agenda control (Cox and McCubbins 2011). CotW is one such device that the majority can use to advance business with a reduced quorum of 100 members, an artifact of Reed's Rules (Beth and 
Fauntroy 2002). ${ }^{17}$

The majority party in the 1980s and early 1990s moved to carry out increasing amounts of business in Committee of the Whole, such as amending bills and moving along procedural votes, to bypass the quorum of 218 members. The addition of up to five co-partisan delegates to CotW improved the majority party's odds of reaching the reduced quorum of 100 members and passing business at a moment's notice. Although nearly all roll call votes in Committee of the Whole counted over three or four hundred members in attendance, much of the business in CotW was done by voice vote, where attendance may have been low (near 100). ${ }^{18}$

The presence of co-partisan delegates in CotW would also act as insurance for majority party members who need to leave the floor to attend other business. These concerns about deploying delegates also motivated the Republican House majority to extend the right to chair CotW to the delegates in 2017, namely the two Republican delegates from Puerto Rico and American Samoa. ${ }^{19}$ Delegates may also substitute for a majority member who is unable to vote on a particular amendment, by preventing the vote margin from slipping low enough to entice moderate members to defect.

\section{Analysis of Committee Membership: Data and Results}

In this section, I use a combination of tests to evaluate the claim that the majority used delegates to pack standing committees and Committee of the Whole. Specifically, I consider the impact of adding delegates on standing committee sizes and the extent to which the majority party is over-represented. I analyze committee membership data from 1970 to 1994, employing regression

\footnotetext{
${ }^{17}$ In the 1970 debate over the Cordova amendment, Rep. Hugh Carey (D-NY), expressed support for delegate voting by pointing out that these new members could help the majority party meet a quorum in standing committees, "[Delegates] might help us to get a quorum on occasion when we cannot get one from our stateside colleagues." Congressional Record, vol. 116 (09-15-1970), pp. 31848-31852

${ }^{18}$ Data are not available for number of members present for voice votes.

${ }^{19}$ Delegates could also serve as the chair of CotW in the 103rd, 110th, 111th, and 115th Congresses, which freed up a member of the majority party to work on other business.
} 
analysis and comparative statistics to evaluate my hypotheses about adding delegates to the committee system. I find support for $\mathrm{H} 2$ and $\mathrm{H} 3$ : the addition of delegates resulted in larger committees in nearly $2 / 3$ of cases and greater Democratic representation in $3 / 5$ of cases. To evaluate the impact of delegate voting in CotW, I estimate the ideal points for each member of the House in the 103rd Congress, and show that the addition of delegates in 1993 moved the CotW median nearly $2 \%$ closer to the majority party.

\section{Democratic over-representation and delegate appointment}

Table 3 presents the results of four regression tests for the relationship between the presence of a delegate on a committee and the degree to which the majority party is over-represented relative to their share of House seats. The dependent variable is the difference between the percent of Democrats on committee $\mathrm{k}$ and the percent of floor seats held by Democrats at time $\mathrm{t}$ (i.e. in a given Congress). The results of models 1 and 2 show that the committees that received delegates between 1961 and 1994 did not, on average, have a greater share of Democrats than other committees.

Not all committees are valued equally, however, and the null results could be due to differences in the partisan makeup of certain committees prior to addition of territorial delegates. High-value committees such as Rules, Ways and Means, and Armed Services, for example, may have already been "packed" and, thus, the majority party did not need to add more members in the form of delegates. To account for this possibility, model 3 includes committee fixed effects and shows that Democrats were over-represented on committees that received delegates by $2.8 \%$ on average. After accounting for changes over time, the results show that the majority enjoyed a $2 \%$ advantage on the committees featuring territorial delegates (model 4).

\section{Standing committee sizes and party balance}

The main tactic the majority party can deploy to tip the party ratio on standing committee in its favor is increasing the size of the committee by adding more majority members (Brady and Lee 
Table 3: Delegates on Committees and Democratic Over-Representation

\begin{tabular}{lcccc}
\hline \hline & \multicolumn{5}{c}{ Dependent variable: } \\
\cline { 2 - 5 } & \multicolumn{4}{c}{ Over-representation (percent) } \\
& $(1)$ & $(2)$ & $(3)$ & $(4)$ \\
\hline Delegate & 0.65 & 0.09 & $2.84^{* * *}$ & $1.80^{* *}$ \\
& $(0.74)$ & $(0.74)$ & $(0.82)$ & $(0.85)$ \\
& & & & \\
Constant & $3.00^{* * *}$ & 0.80 & -0.02 & -1.68 \\
& $(0.39)$ & $(1.48)$ & $(1.15)$ & $(1.56)$ \\
& & & & \\
Congress Fixed Effects & No & Yes & No & Yes \\
Committee Fixed Effects & No & No & Yes & Yes \\
\hline Observations & 336 & 336 & 336 & 336 \\
$\mathrm{R}^{2}$ & 0.00 & 0.12 & 0.38 & 0.48 \\
Adjusted R & \\
\hline \hline
\end{tabular}

Note: ${ }^{*} \mathrm{p}<0.1 ;{ }^{* *} \mathrm{p}<0.05 ;{ }^{* * *} \mathrm{p}<0.01$

2016). The property rights norm protects the current committee members from being removed from their seats, but the majority can bypass the norm and shift the median voter toward the party's ideal position by expanding the number of seats (Brady and Lee 2016). Committee sizes were changing through the 1970s and 1980s and it is at least plausible that the majority party used the expansion strategy during this period to pack committees with delegates.

Table 4: The effect of delegate appointments on committee size, 93rd-103rd Congresses

\begin{tabular}{|l|c|}
\hline Number of delegate appointments such that $\Delta N_{k t}>0$ & $14(64 \%)$ \\
\hline Number of delegate appointments such that $\Delta N_{k t}=0$ & $2(9 \%)$ \\
\hline Number of delegate appointments such that $\Delta N_{k t}<0$ & $6(27 \%)$ \\
\hline Total number of new delegate appointments & 22 \\
\hline
\end{tabular}

In order to test this claim, I examine how committee size and the rate of Democratic overrepresentation changed when a new delegate was appointed to a particular committee. ${ }^{20}$ I identify

\footnotetext{
${ }^{20}$ Data on committee membership from Nelson (n.d.) and Stewart \& Woon (2017), both accessed 12/2017.
} 
all the new appointments of a delegate representing territory $\mathrm{j}$ to a committee $\mathrm{k}$ at time $\mathrm{t}>1970$, totalling 22 appointments between the 93rd and 103rd Congresses. For each new appointment, I calculate the change in committee size over time, $\Delta \mathrm{N}_{k t}=\mathrm{N}_{k t}-\mathrm{N}_{k, t-1}$, where $\mathrm{N}_{k t}$ is the number of seats on committee $\mathrm{k}$ at time $\mathrm{t}$. Thus $\Delta \mathrm{N}_{k t}$ is positive if the committee grew in size when the new delegate was appointed, 0 when the committee did not change in size, and negative if the committee was reduced in size. Table 4 presents the results of this test of the committee size hypothesis, $\mathrm{H} 2$ . Nearly two thirds (64\%) of new delegate appointments were associated with an increase in the number of committee seats, while a quarter (27\%) of appointments were associated with smaller committee sizes.

Next, I calculate changes in the rate of majority party representation on committees that receive a new delegate to test the over-representation hypothesis, H3. Committees are considered "packed" when there is a higher proportion of majority party members, in this case Democrats, than their party's share of floor seats. For each new appointment, I calculate $\Delta \mathrm{OVER}_{k t}=\mathrm{OVER}_{k t}$ - $\mathrm{OVER}_{k, t-1}$, where $\mathrm{OVER}_{k t}$ is the over-representation of Democrats on committee $\mathrm{k}$ at time $\mathrm{t}$. Thus, $\mathrm{OVER}_{k t}$ is positive if the Democrats became more over-represented when a new delegate was appointed, 0 if there was no change, and negative if Democrats became less over-represented. Table 5 presents a summary of the results. Nearly three fifths of new delegate appointments (59\%) were associated with an increase in the share of committee seats held by Democrats relative to their share of seats on the floor. Nine appointments (41\%) were associated with a decline in Democratic over-representation, although in each case the party continued to be over-represented relative to the floor.

Table 5: Delegate committee appointments and Democratic over-representation, 93rd-103rd Congresses

\begin{tabular}{|l|c|}
\hline Number of delegate appointments such that $\triangle O V E R_{k t}>0$ & $13(59 \%)$ \\
\hline Number of delegate appointments such that $\triangle O V E R_{k t}=0$ & 0 \\
\hline Number of delegate appointments such that $\triangle O V E R_{k t}<0$ & $9(41 \%)$ \\
\hline Total number of new delegate appointments & 22 \\
\hline
\end{tabular}




\section{Evidence in Committee of the Whole}

In order to evaluate the impact of delegate voting in CotW, I test whether the addition of delegates changed the median voter in that body. Previous studies of roll call voting in Committee of the Whole tend to drop the delegates from the data, even in those Congresses where they could cast votes (c.f. Roberts and Smith 2003). The result, unfortunately, is that the data are not readily available to estimate the delegates' ideal points in CotW, and that existing ideal point estimates for other legislators are biased, if they are based on the nearly 1,200 roll call votes taken in sessions where delegate votes were omitted. The size and direction of the bias are not clear, although the bias associated with the absence of five members out of 440 total House members, in just three sessions, is unlikely to have had an appreciable impact on any major findings about Congress.

To remedy this issue, I collect the delegates' votes in 1,173 roll call votes in three Congresses to estimate each members' ideal point. ${ }^{21}$ House roll call data were collected from VoteView and delegates' CotW votes were found on Congress.gov. First, I calculate the median member in CotW, as well as the median House Democrat and House Republican based on the roll call votes excluding the delegates. Next, I add the delegates' votes on roll call items in CotW and re-estimate each members' ideal points, the party medians, and the CotW floor median.

Table 6 presents estimated ideal points from a binary item response model (IRT) using yes and no votes coded 1 and -1, respectively. The estimates for House member ideal points are then scaled between -1 and 1 . The results are consistent with our expectations: the CotW median is closer to the median Democrat in the House compared to the CotW median as calculated without the delegates. In the 103rd Congress, the average ideal point estimate for the delegates was -0.24 , just to the right of the median Democrat (-0.28) and to the left of the median House member (-0.04). The addition of the delegates shifts the CotW to the left by 0.02 , equivalent to approximately $2.4 \%$ of the distance between the median Democrat and Republican (0.84). ${ }^{22}$ Returning to the analogy

\footnotetext{
${ }^{21}$ To estimate legislators' ideal points in CotW, I use the emIRT package in R (Imai, Lo, and Olmsted 2016).

${ }^{22}$ This result may be attenuated by the inclusion of all roll call votes from CotW, including uncontroversial amendments that passed with large bipartisan majorities.
} 
Table 6: Moving the median with delegates in Committee of the Whole

\begin{tabular}{|c|c|c|c|c|c|}
\hline Congress & $\begin{array}{c}\text { Dem. Delegates } \\
\text { left of median }\end{array}$ & $\begin{array}{c}\text { Dem. Delegates } \\
\text { right of median }\end{array}$ & $\begin{array}{c}\text { Movement } \\
\text { of median }\end{array}$ & $\begin{array}{c}\text { Avg Member } \\
\text { Attendance }\end{array}$ & $\begin{array}{c}\text { Delegate } \\
\text { Attendance }\end{array}$ \\
\hline 103rd & 4 & 1 & -0.018 & $96.1 \%$ & $84.2 \%$ \\
\hline 110th & 2 & 2 & -0.001 & $96.5 \%$ & $77.0 \%$ \\
\hline 111th & 0 & 6 & +0.009 & $96.7 \%$ & $82.0 \%$ \\
\hline
\end{tabular}

of a tightly-contested campaign (Section 2.2), it is worth considering whether a political party would think it is worthwhile to pursue a strategy that moves the vote margin by $2.4 \%$ on average. Committee packing with delegates is no panacea, but the effect on the margins makes it worthwhile in the modern era of increasing partisan warfare.

Previous studies show that the CotW median tended to be more conservative than the floor median, but we do not need to display the floor median here to test the claim about committee packing. The key assertion in this section is that the majority party sought to shift the CotW median toward the majority party median (i.e. to the left). That claim is borne out by the evidence. Previous research shows the CotW median was to the right of the floor median leading up to 1993 (Roberts and Smith 2003), which further reinforces that Democrats had an incentive to pursue this strategy. The majority might have pursued the expansion strategy even if the CotW and floor medians were the same: Democrats had lost ten seats in the 1992 elections and faced a rightward shift in the floor median in 1993. The addition of five Democratic delegates halved those losses and moderated the rightward shift of the CotW median no matter where the floor median lay.

In later years, the addition of delegates to CotW had a negligible effect on the CotW median, which was further to the left in 2007-2011 than 1993-1995. The average attendance rate for delegates was lower in the later Congresses, and the delegates with the highest ideal point estimates (i.e. less liberal) tended to miss the most votes. ${ }^{23}$ It is plausible the majority party relied on the delegates in CotW less over time as polarization increased and party cohesion rose.

${ }^{23}$ Among the Democratic delegates in the 110th-111th Congresses, the American Samoa and Guam delegates were the least liberal and missed the most votes. It is worth noting that the delegates from these territories must travel farther from their district to Capitol Hill than any other member: between 7,000 and 8,000 miles. 


\section{Opposition to delegate voting}

To provide an additional test of the claim that the majority party used delegates to pack standing committees, it is worthwhile to examine the extent and form of the minority party's opposition to these reforms. If the majority party did pursue a packing strategy, we would expect to observe the other party taking steps to mitigate the impact of delegates after a change in party control of the House.

\section{Opposition to delegate voting in standing committees}

Objections to delegate voting in standing committees centered on the reform's constitutionality, as well as the impact of the Cordova amendment in the long term. A warning from the floor manager, B.F. Sisk, a conservative Democrat from California, is illustrative of the skeptics' concerns in 1970: "I am very much concerned about the precedents that you are setting because what we are talking about may well apply to Delegates who come to the House in the future...[We] have a number of islands out in the trust territories...the Micronesians, the Samoans, and the Guamanians...who some day may want Delegate representation...I would only ask that the Members look very carefully at what the long-range results of this could be. I have very grave questions about the constitutionality of it. But I think there are even far more serious implications than merely that of constitutionality.",24

There is evidence that Republicans and some conservative Democrats were opposed to the creation of new delegate seats in the 1970s, although the measures passed comfortably. Figure 3 shows the party breakdown on the vote to create the D.C. delegate, and figure 4 presents the same for the vote to create delegates for Guam and the U.S. Virgin Islands (note: Aye votes are represented by empty dots, Nay votes by solid dots). The two votes were not particularly close but the partisan breakdown of the opposition is consistent with the theory presented in this paper. Although most Democrats and Republicans supported creating a delegate for D.C. (314-68), many

\footnotetext{
${ }^{24}$ Congressional Record, vol. 116 (09-15-1970), pp. 31848-31852
} 
of the most conservative members of the two parties were opposed. Southern Democrats, in particular, joined many Republicans on the right to vote against the new seat. This pattern of opposition was more pronounced in the vote two years later to create the Guam and USVI delegates (251123). Several liberal Republicans joined others in their party, along with many conservative and moderate Democrats, to oppose these two seats.

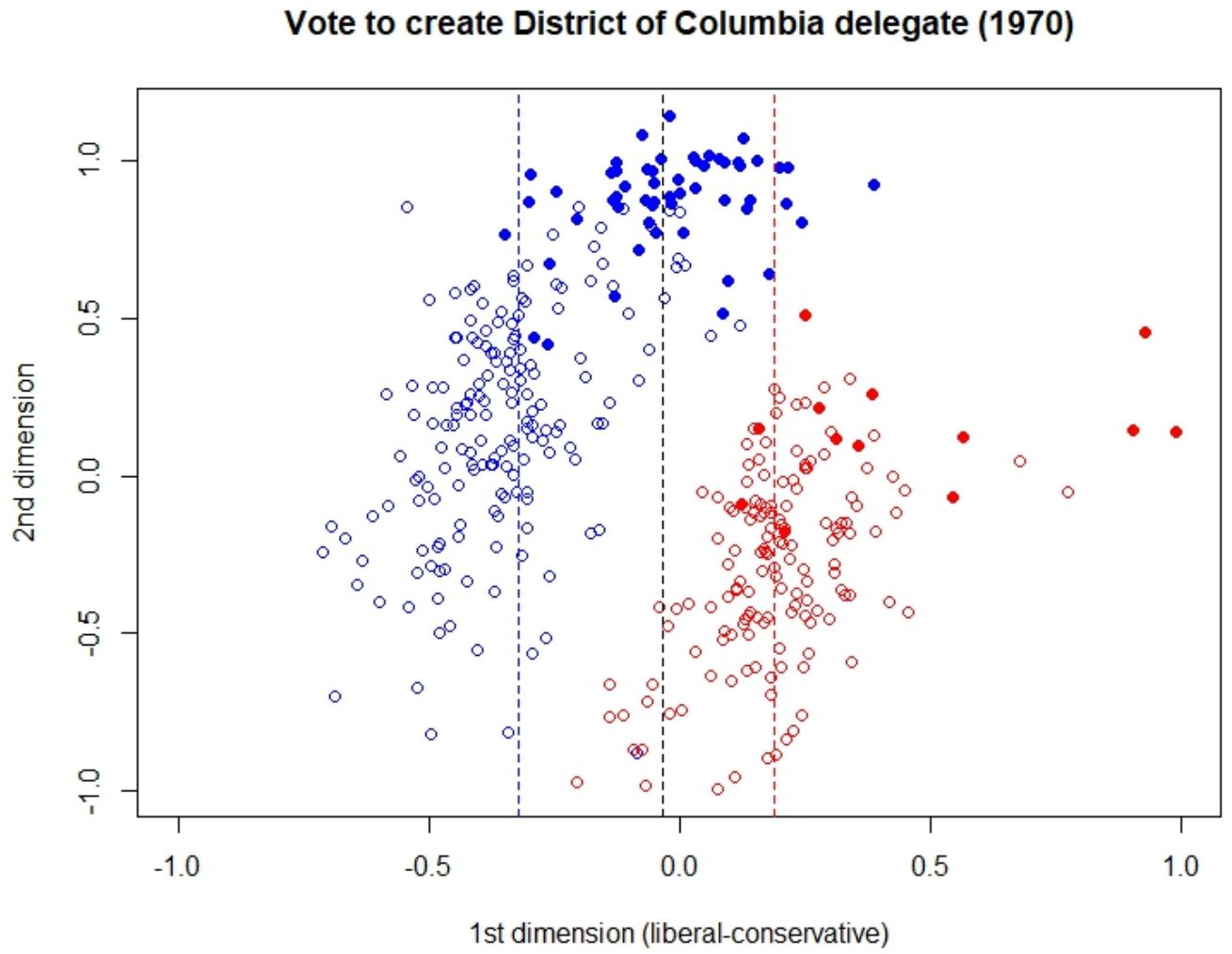

Figure 1: Aye votes are empty dots, Nay votes are solid dots. Democrats are blue, Republicans are red.

What could the Republicans do, once they gained the majority, to protect against the effects of delegate voting? In the case of standing committees, Republican leadership did not need to remove delegates from the committee system altogether to mitigate their influence. Since the majority party exercises discretion over the party ratios on standing committees, and given that most delegates were minority party members (that is, they were Democrats), their votes in committee would be outweighed by majority members. 


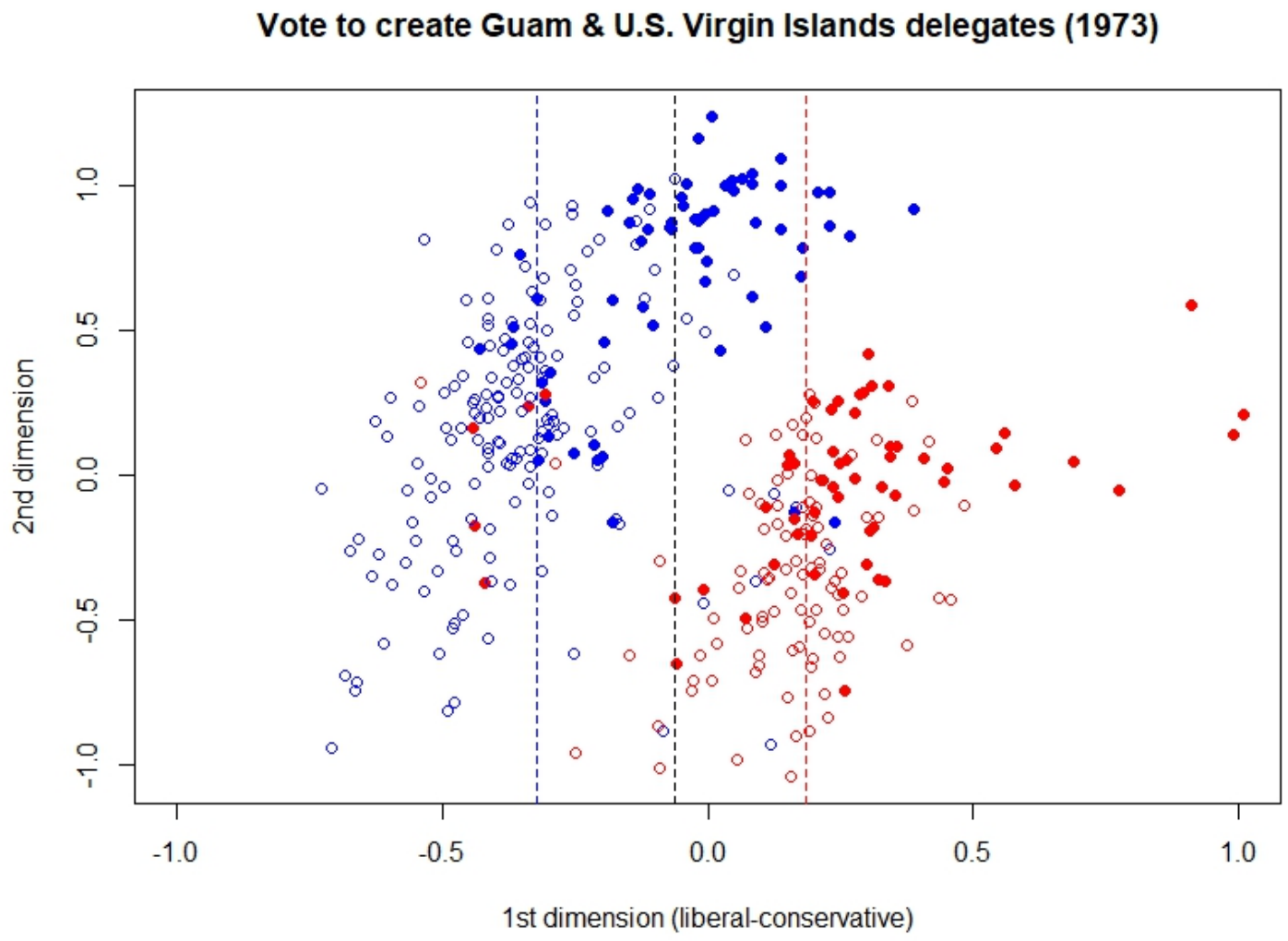

Figure 2: Aye votes are empty dots, Nay votes are solid dots. Democrats are blue, Republicans are red.)

One possible explanation for conservative opposition to the reforms that empowered delegates may be that Republicans and their allies oppose the continued existence of delegate seats, and thus do not support granting new privileges to delegates on principle. This explanation is not supported by the record: Republicans have sponsored legislation to create delegate seats for other territories and have been generally supportive of the institution.

In 1977, for example, six conservatives led by Senator Jesse Helms (R-NC) sponsored a bill to create a new delegate for Americans living in the Panama Canal Zone. The bill never received a vote, however, since the Senate and President Carter were concurrently debating the return of the Canal Zone to Panama. Decades later, Republicans were also instrumental in the push for a delegate from the Northern Mariana Islands, introducing early legislation for that purpose in 1996 and 2005. Although these bills were unsuccessful at the time, they suggest that Republicans are not 
opposed to the delegates' existence, but that their opposition to delegate voting may be a calculated choice to block any reform that would disadvantage the GOP in the legislative process.

\section{Opposition to delegate voting in CotW}

"Let me just make this point: This proposal is a classic welfare-state power grab...[For] the Democratic leadership, by vote of a majority, to muscle through five Delegates being allowed to vote on the floor of the House is unconstitutional, as I think we will prove in a lawsuit, and is an offense to every taxpaying citizen of the United States."

Rep. Newt Gingrich (R-GA) in 1993 debate over delegate voting in Committee of the Whole

A skeptic of the theory about Democrats using territorial delegates to pack CotW might wonder: if the majority's agenda was being thwarted by the conservative coalition, how did party leaders manage to pass this reform? If the conservative coalition could foresee the effect of delegate voting in CotW, why did the coalition not prevent the reforms from passing in the first place? First, Republicans were overwhelmingly opposed to delegate voting in CotW, and went to great lengths to stop it. Twelve Republicans, including leadership, sued in federal court to prevent the delegates from voting even after Democrats included a provision to make the delegates' votes non-pivotal. Republicans also had the support of the national media, which largely characterized delegate voting as a "power grab". ${ }^{25}$ The timing of the reform, after Democrats had lost House seats in the 1992 election, also drew the ire of skeptics: "The plain truth is that because Republicans gained 10 seats last November, the Democrats are trying to undo the electoral process by this parliamentary rule change." 26

If Republicans were united in opposing delegate voting in CotW, why did conservative Democrats not ally with Republicans to block the reform? The key dilemma faced by the majority party in

\footnotetext{
25 "Have the House Democrats No Shame?", New York Times, Dec 29, 1992; "Foley on a D.C. tightrope", Washington Post, Dec 20, 1992; "The Democrats' Greedy Power Grab", Chicago Tribune, Dec 30, 1992; Conservative columnist George F. Will also opposed the measure in the Baltimore Sun: "How to Get More Democrats in House Than Constitution Allows", Dec 17, 1992.

${ }^{26}$ Rep. Don Manzullo (R-IL), Congressional Record, Jan 5, 1993, pp. 45-122
} 
CotW was lower cohesion on CotW votes relative to floor votes. Democratic members closed ranks on floor votes in early 1993, including the vote to adopt delegate voting in CotW. With carrots and sticks, the leadership ensured it was not worthwhile for conservative Democrats to sink the rules package over delegate voting. Second, even if moderate-conservative Democrats were wary of the delegates' impact on amendment votes in CotW, they likely faced pressure from within the party to support the delegates, especially from Rep. Norton and her liberal allies. Not only could the delegates be helpful as co-sponsors on legislation, they were also valuable partners in the standing committees, where a delegate serving as subcommittee chair could doom another member's bill. For Democrats who might otherwise ally with Republicans in CotW, the incentives to support co-partisan delegates outweighed the payoffs of opposing delegate voting.

Minority leader Robert H. Michel and other Republicans argued that the expansion of delegates' rights in Committee of the Whole was unconstitutional, in part, because it granted legislative power to members that did not represent states. The plaintiffs also noted that the rule change halved the majority party's seat losses in the previous year's election. The Democratic defendants argued that the House rules grant the majority the power to amend the committee system, and that CotW was more akin to a standing committee than the House floor (Palmer 2006, Beth and Fauntroy 2002). Almost any action taken in CotW, including amendments passed with the support of the territorial delegates, could be reconsidered on the House floor if 25 members rose with such a demand. The controversy surrounding delegate voting in Committee of the Whole centered on the extent to which delegates were exercising legislative power. Federal courts found that CotW is a creation of House rules and decisions made there are reversible by the House itself. Only four votes were automatically taken because of this rule in the six years that delegates possessed the right to vote in CotW. Judges on the U.S. District Court of D.C. and U.S. Court of Appeals for the D.C. Circuit upheld the rules changes and suggested that the pivotality rule made the delegates' votes "meaningless". 27

In addition to bloc voting against the enacting legislation and litigating the issue in federal

\footnotetext{
${ }^{27}$ Michel v. Anderson, 817 F. Supp. 147-148 (District of D.C. 1993); Michel v. Anderson, 14 F.3d 623 (D.C. Circuit 1994).
} 
court for over a year, Republicans also changed their behavior in CotW once delegates started voting. Republicans argued that the majority overstepped its bounds to gain an advantage in policymaking, but despite minority fears about the majority abusing the delegates to pass "close" votes, the delegates were only decisive on four votes in CotW across three Congresses, and only one automatic re-vote led to the outcome being reversed. ${ }^{28}$

Even if the delegates could not be pivotal, House Republicans acted as though their votes mattered by demanding significantly more re-votes on amendments passed in CotW than in previous Congresses. Nearly 10 percent of amendments passed in CotW were brought up for a re-vote on the floor, although some members did switch their votes, very few outcomes changed (Espino and Canon 2009). Figure 3 shows the precipitous rise in re-votes that House members, mostly Republicans, demanded in the 103rd Congress. ${ }^{29}$ The pattern is consistent with the idea that the minority party was responding to the majority party's packing strategy and the use of CotW to pass legislative business under a more favorable set of rules.

The most likely explanation is that Republican opposition to delegate voting is the product of a rational calculation about the party's success under the two alternate scenarios. According to this calculation, Republicans believe their odds of passing or blocking policy will be worse off if the territorial delegates can vote in Committee of the Whole. These concerns were echoed by Republicans and conservative Democrats about delegates voting in standing committees in the 1970s.

Another criticism of delegate voting from a minority party leader, Rep. Gerald Solomon, is suggestive of why Republicans opposed even non-pivotal delegate voting. Rep. Solomon was confident that Democrats could trade votes to ensure that delegates' votes never appeared pivotal. He warned about "the kind of vote trading and deals which might be cut to ensure that the Delegate vote does not make the critical difference...That is what we are concerned about. We want them to

\footnotetext{
${ }^{28}$ The delegates cast decisive votes on three amendments in the 103rd Congress: roll call \#63 (03/17/1994), roll call \#267 (06/23/1994), and roll call \#277 (06/24/1994). The delegates were decisive once in the 111th Congress: roll call \#360 (06/18/2009).

${ }^{29}$ Three re-votes were triggered by the delegates' non-pivotal rule, while the other 59 were requested by House members.
} 


\section{Re-votes on amendments from Committee of the Whole}

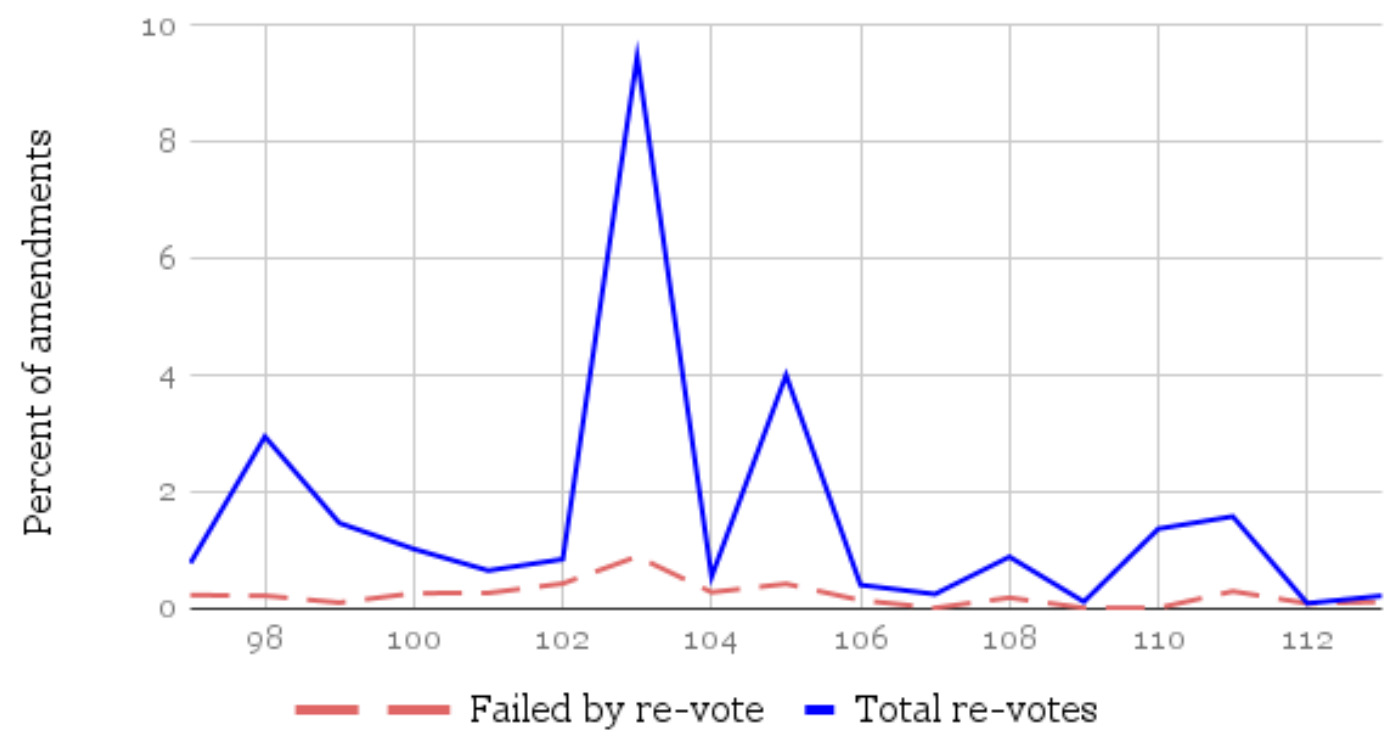

Figure 3: Republican obstruction of delegate voting

participate just the way they are now and they do a darn good job at it."

Solomon argued, in particular, that delegates could exercise negative agenda control despite the 'savings clause' that stipulated their votes cannot be pivotal. Under the 1993 rules, amendments that passed or failed with a vote margin within the pivotal window (the number of delegates who voted on that particular measure, up to 5) would be automatically subject to re-vote, and any 25 members could force any amendment passed in CotW to be reconsidered on the floor. Members of the House could not, however, force a re-vote on an amendment that failed in CotW by a vote margin outside the pivotal window. Thus, it was possible for territorial delegates to pad a vote margin just outside the pivotal window, making a vote look closer than it was and making it harder to negotiate with the truly pivotal members. In this case, the minority party would not retain the ability to force a floor vote to consider, and Solomon suggested this dynamic was at play in a vote on the Selective Service System in 1993 (CQ Almanac 1993).

The claim that the territorial delegates exercised out-sized legislative power in CotW by masking the vote margin between regular members is dubious: House members know that the delegates' 
votes cannot be pivotal and should thus be aware of the 'true' vote margin during negotiations. Even if Rep. Solomon's assessment is accurate, it is hard to identify other cases where this might have happened. Only 28 of 1,158 votes $(2.4 \%)$ were within single digit margin, including the four votes that were automatically retaken (only one of which changed outcome) and the Selective Service case. Just two amendments were failed and then automatically re-voted on due to the 'savings clause'. Eighteen other amendments (1.6\%) failed by single digit margins but could not be reconsidered on the floor because the delegates' votes were not pivotal.

Republicans were also worried that delegates would not only vote to pass or defeat amendments, but also exercise procedural control over CotW that would meaningful impact policymaking. For example, one representative worried that delegates would provide increasingly helpful to Democrats as leadership moved more business into CotW: "The fact that the House is increasingly considering important measures under restrictive amendment rules means that votes in the Committee of the Whole are all the more critical and likely to be binding on the House-especially on king-of-the-hill amendment procedures or on bills on which only one substitute is allowed. Even if such a ruling is appealed, delegates may provide the deciding vote as to whether the chair's ruling is upheld or overruled". 30

Republicans also worried that delegates, presiding over the CotW, would thwart their own attempts to game the procedures on the floor. "Non-Member chairing of the Committee of the Whole means that a non-Member of the House as presiding officer could issue critical rulings on such things as the germaneness of amendments, thereby possibly precluding the Committee and the House from even considering certain amendments if they are ruled out of order. Moreover, such rulings constitute binding precedents on the House if a similar situation should arise in the House." 31 Thus, even if the delegates were not legally allowed to be pivotal voters in CotW, Democrats found it worthwhile to implement the rule changes anyway, and Republicans saw sufficient threat to oppose delegate participation.

\footnotetext{
${ }^{30}$ Congressional Record, Jan 5, 1993, pp. 45-122

${ }^{31}$ Congressional Record, Jan 5, 1993, pp. 45-122
} 


\section{Conclusion}

This paper makes multiple contributions to the literature on committees and partisanship in Congress. First, I show that the majority party possesses two previously unknown tools to gain advantage in the legislative process: adding new delegates to pack standing committees and granting delegates voting rights in order to pack the Committee of the Whole. These strategies are absent from the literature on partisan theories of Congress, despite the near-continuous fighting between the two parties over the delegates' rights whenever majority control of the House changes hands.

Second, I show that the majority party had the right incentives, and the legal authority, to employ these strategies in the latter quarter of the 20th century, to push back against the conservative coalition that was obstructing their agenda in standing committees and CotW. The majority passed legislation and rules changes to create new delegates and expand their committee rights in the 1970s with overwhelming support from liberals and sizable opposition from Republicans and conservative Democrats, suggesting the two factions were at odds over the impact of such reforms. This paper presents the first statistical evidence that these changes in the House rules allowed the majority party to increase its representation on standing committees, as well as CotW.

The results show that the CotW median was closer to the majority party median when we include the delegates' votes than when the delegates are excluded, at least in the 103rd Congress. In the 110th and 111th Congresses, the delegates were not systematically closer to the majority party median than the CotW median, and thus did not apply the same leftward pressure that delegates appear to have applied in the 103rd Congress. These results suggest that although the addition of delegates to committees can occur during periods of high polarization, the addition of delegates does not itself contribute to party polarization.

Finally, a key insight from this research is that the tools in the majority party's toolkit are not all equal in effect size. The extant literature points to high-impact strategies that allow the party leadership to maximize their control over the policy-making process, but there are those tools like committee packing that can be deployed on the margins. I do not make a claim about the effect that delegate voting had on committee activity or policymaking, in the strict sense that I cannot 
say which policy outcomes would have been different if the delegates had not participated in the committee system.

The past 50 years of delegate participation in Congress was the product of party strategy, procedural control, and institutional change. Taken together, the theory and empirical results in this paper show us that majority leadership is willing to consider any strategy to give their party an advantage, no matter how peripheral the tactic or nominal the impact. Substantively, these results contribute to our knowledge of an understudied institution that represents over 5 million Americans. 


\section{References}

Aldrich, John H., and David W. Rohde. (2000). The consequences of party organization in the House: The role of the majority and minority parties in conditional party government. Polarized politics: Congress and the President in a partisan era.

Aldrich, John, and David W. Rohde. (2001). The logic of conditional party government: Revisiting the electoral connection. Congress Reconsidered, ed. Dodd, Lawrence and Bruce Oppenheimer, 7th edition. Washington, DC: Congressional Quarterly Press.

Bach, Stanley J., and Steven S. Smith. (1988). Managing uncertainty in the House of Representatives: adaption and innovation in special rules. Brookings Institution Press, 1988.

Beth, Richard S., and Michael K. Fauntroy. (2002). Is the Committee of the Whole the House? Implications of Michel v. Anderson for District of Columbia Representation. Paper delivered at annual meeting of American Political Science Association.

Binder, Sarah A. (1996). The partisan basis of procedural choice: Allocating parliamentary rights in the House, 1789-1990. American Political Science Review 90.1: 8-20.

Brady, Michael C., and Daniel Lee. (2016). Another tool in the party toolbox? Tracing the strategic expansion of committee size in the US House, 1947-2010. Party Politics 22.6: 784-796.

Broder, David S. "Foley on a D.C. tightrope.” The Washington Post, Dec 20, 1992.

Delegates got 'symbolic' floor vote. (1994). CQ Almanac 1993, 49th ed., 75-76. Washington, DC: Congressional Quarterly.

Espino, Rodolfo, and David T. Canon. "Vote switching in the US House." The Journal of Politics 71.1 (2009): 324-338.

Holtzman, Abraham. (1986). Empire and representation: The U.S. Congress. Legislative Studies Quarterly vol. 11, no. 2: 249-273. 
Imai, Kosuke, James Lo, and Jonathan Olmsted. (2016). Fast estimation of ideal points with massive data. American Political Science Review 110.4: 631-656.

Jenkins, Jeffery A., and Nathan W. Monroe. (2014). Negative agenda control and the conservative coalition in the US House. The Journal of Politics 76.4: 1116-1127.

Lazarus, Jeffrey, and Nathan W. Monroe. (2007). The Speaker's discretion: Conference committee appointments in the 97th through 106th Congresses. Political Research Quarterly 60.4: 593-606.

Lewallen, Jonathan. (2017). From rules to representation: Teaching about the territories and their delegates in the US Congress.” PS: Political Science \& Politics vol. 50, no. 2: 497-500.

Lewallen, Jonathan, and Bartholomew H. Sparrow. "Nothing on the Floor: Congress, the Territorial Delegates, and Political Representation.” Political Science Quarterly 133.4 (2018): 729-752.

Lewis, Jeffrey B., Keith Poole, Howard Rosenthal, Adam Boche, Aaron Rudkin, and Luke Sonnet. (2017). Voteview: Congressional Roll-Call Votes Database.

McCarty, Nolan, Keith Poole and Howard Rosenthal. (2000). Congress and the territorial expansion of the United States. New directions in studying the history of the U.S. Congress, David Brady and Mathew McCubbins (eds). Stanford: Stanford University Press.

Nelson, Garrison. (n.d.) Committees in the U.S. Congress, 1947-1992, [House/87th-102rd], [Accessed: 12/01/2017].

Palmer, Betsy. (2006). Territorial delegates to US Congress: Current issues and historical background. Congressional Research Service. 
Roberts, Jason M., and Steven S. Smith. (2003). Procedural contexts, party strategy, and conditional party voting in the US House of Representatives, 1971-2000. American Journal of Political Science 47.2: 305-317.

Roberts, Jason M. (2007). The statistical analysis Of roll-call data: A cautionary tale. Legislative Studies Quarterly 32.3: 341-360.

Rohde, David W. (1991). Parties and leaders in the postreform House. University of Chicago Press.

Schickler, Eric, and Andrew Rich. (1997). Controlling the floor: Parties as procedural coalitions in the House. American Journal of Political Science: 1340-1375.

Sinclair, Barbara. (2006). Party Wars: Polarization and the politics of national policy making. Norman: University of Oklahoma Press.

Smith, Steven S. (1989). Call to order: Floor politics in the House and Senate. Brookings Inst Press.

Stewart, Charles, and Barry R. Weingast. (1992). Stacking the Senate, changing the nation: Republican rotten boroughs, statehood Politics, and American political development. Studies in American Political Development 6.02: 223-271.

Stewart, Charles and Jonathan Woon. (2017). Congressional committee assignments, 103rd to 114th Congresses, 1993-2017: [House], [Accessed: 12/01/2017].

Vander Wielen, Ryan J., and Steven S. Smith. (2011). Majority party bias in US congressional conference committees. Congress \& the Presidency. Vol. 38, No. 3. Taylor \& Francis Group. 


\section{Appendix}

Table 7: New delegate appointments to standing committees, 93rd to 103rd Congress

\begin{tabular}{|c|l|c|c|}
\hline Congress & Committee & Committee Size & Dem. Over-representation \\
\hline 93rd & Education and Labor & Decrease & Decrease \\
93rd & Banking and Currency & Increase & Decrease \\
93rd & District of Columbia & Increase & Decrease \\
93rd & Interior \& Insular Affairs & Increase & Decrease \\
94 th & Banking, Currency, Housing & Decrease & Increase \\
94 th & Interior \& Insular Affairs & Increase & Increase \\
94 th & Merchant Marine \& Fisheries & Increase & Increase \\
95 th & Education and Labor & Decrease & Increase \\
95 th & Interior \& Insular Affairs & Increase & Increase \\
97 th & Merchant Marine \& Fisheries & Decrease & Decrease \\
97 th & Public Works \& Transportation & No effect & Decrease \\
97 th & Veterans Affairs & No effect & Decrease \\
97 th & Post Office \& Civil Service & Increase & Increase \\
99th & Interior \& Insular Affairs & Decrease & Decrease \\
99 th & Banking, Finance, Urban Affairs & Increase & Decrease \\
100th & Foreign Affairs & Increase & Increase \\
101st & Education and Labor & Increase & Increase \\
102nd & Foreign Affairs & Decrease & Increase \\
102 nd & Education and Labor & Increase & Increase \\
102 nd & Merchant Marine \& Fisheries & Increase & Increase \\
102 nd & Public Works \& Transportation & Increase & Increase \\
103 rd & Education and Labor & Increase & Increase \\
\hline
\end{tabular}

